\title{
All-inorganic inverse perovskite solar cells using zinc oxide nanocolloids on spin coated perovskite layer
}

\author{
Naoyuki Shibayama ${ }^{1 *} \mathbb{0}$, Hiroyuki Kanda', Shin-ichi Yusa², Shota Fukumoto ${ }^{1}$, Ajay K. Baranwall', Hiroshi Segawa ${ }^{3}$, \\ Tsutomu Miyasaka ${ }^{4}$ and Seigo Ito $^{1 *}$
}

\begin{abstract}
We confirmed the influence of $\mathrm{ZnO}$ nanoparticle size and residual water on performance of all inorganic perovskite solar cells. By decreasing the size of the $\mathrm{ZnO}$ nanoparticles, the short-circuit current density (Jsc) and open circuit photovoltage (Voc) values are increased and the conversion efficiency is improved. Although the Voc value is not affected by the influence of residual water in the solution for preparing the ZnO layer, the Jsc value drops greatly. As a result, it was found that it is important to use the oxide nanoparticles with a small particle diameter and to reduce the water content in the oxide forming material in order to manufacture a highly efficient all inorganic perovskite solar cells.
\end{abstract}

Keywords: Perovskite solar cell, $\mathrm{ZnO}$ nanoparticle, $\mathrm{NiO}_{x^{\prime}}$ Spray pyrolysis deposition

\section{Background}

The rapid development of organic-inorganic metal halide perovskite $\left(\mathrm{CH}_{3} \mathrm{NH}_{3} \mathrm{PbI}_{\mathrm{x}} \mathrm{Br}_{3-\mathrm{x}}\right)$ based solar cells has attracted worldwide attention due to the material's high absorption coefficient, small exciton binding energy, and long carrier diffusion length [1-4]. This rapidly increasing conversion efficiency achieving from initial 3.81 to $22.1 \%$, have been realized in period of the 7 years [5-9]. Since the perovskite is an inexpensive material and fabricated solar cell has a simple device structure owing to its solution process, it has the possibility to replace the commercially established solar cell such as $\mathrm{Si}$, CIGS, and CdTe solar cells $[10,11]$. In the commonly reported perovskite solar cells, organic materials (Spiro-OMe-TAD, PCBM, $\mathrm{C}_{60}$ ) on top of perovskite active layer having an energy level conforming to the perovskite layer and having good conductivity are used to support the efficient charge collection on top of perovskite active layer [12, 13]. Since these organic materials require high grade

*Correspondence: naoyuki.shibayama81@gmail.com; itou@eng.u-hyogo. ac.jp

${ }^{1}$ Department of Materials and Synchrotron Radiation Engineering, Graduate School of Engineering, University of Hyogo, 2167 Shosha, Himeji, Hyogo 671-2280, Japan

Full list of author information is available at the end of the article purity, they are very expensive. Moreover, they are likely to be the cause of lowering the durability of perovskite solar cells. Accordingly, the development of inexpensive and highly durable materials are required. Researches have been conducted to utilize inorganic materials $(\mathrm{CuI}$, $\mathrm{CuSCN}, \mathrm{Cu}_{2} \mathrm{O} / \mathrm{CuO}$ ) as a novel hole transporting layer (HTL) on the perovskite active layer in place of commonly employed organic layers [14-20].

In recent years, all inorganic based perovskite solar cells using oxide nanoparticles $\left(\mathrm{ZnO}, \mathrm{SnO}_{2}, \mathrm{Zn}_{2} \mathrm{SnO}_{4}\right)$ as the electron transporting layer (ETL) by using the $\mathrm{NiO}_{x}$ layer which in the HTM layer as a scaffold have been reported [21-23]. Although the reported conversion efficiencies were inferior to that of perovskite solar cells using organic materials, all inorganic perovskite solar cells using oxide nanoparticles have been found to exhibit high durability. However, guidelines for improving the performance of all inorganic perovskite solar cells using oxide nanoparticles on the perovskite active layer are still unknown.

In this study, we fabricated all inorganic perovskite solar cells and investigated the influence of oxide nanoparticle size and its role towards solar cell performance. In addition, we investigated the effect of synthesis route on the performance and durability of the fabricated cells. 
The synthesized $\mathrm{ZnO}$ nanoparticles were used as ETL in fabricated all inorganic inverted perovskite solar cell where $\mathrm{NiO}_{x}$ layer formed the scaffold. The results of this study can provide guidelines for using nanoparticles in all inorganic perovskite solar cells.

\section{Experimental}

\subsection{Materials}

All solvents and chemicals were purchased and utilized as obtained. Nickel (II) acetylacetonate, zinc acetate and bathocuproine (BCP) were purchased from SigmaAldrich Co. LLC. $\mathrm{CH}_{3} \mathrm{NH}_{3} \mathrm{PbI}_{3}$-DMF (MAPbI $-\mathrm{DMF}$ ) was purchased from TCI Co., Ltd. All solvents and reagents were of the highest quality available and were used as received.

\subsection{Synthesis of $\mathrm{ZnO}$ nanoparticles solution and powders 2.2.1 Aqueous process}

$\mathrm{ZnO}$ nanoparticle_aque was synthesized following protocol in the previously published literature [24]. To synthesize the $\mathrm{ZnO}$ nanoparticles by the aqueous process, the $250 \mu \mathrm{L}$ deionized water was added to $4.46 \mathrm{mmol}$ zinc acetate powder to make solutions. Further $42 \mu \mathrm{L} \mathrm{CH}_{3} \mathrm{OH}$ was added dropwise for $30 \mathrm{~min}$ at room temperature and $\mathrm{Zn}$ precursor solution was obtained. In the next step, $\mathrm{KOH}(7.22 \mathrm{mmol})$ was dissolved in $\mathrm{CH}_{3} \mathrm{OH}(23 \mathrm{~mL})$ to make $\mathrm{KOH}$ solution. The $\mathrm{Zn}$ precursor solution was refluxed and, $\mathrm{KOH}$ solution was added dropwise into the flask maintaining time duration $15 \mathrm{~min}$. Then, the mixture was refluxed for $30 \mathrm{~min}$. The colloidal solution was replaced by isopropanol from water using a rotary evaporator and the concentration of $\mathrm{ZnO}$ was adjusted to $0.2 \mathrm{wt} \%$ [25-28].

\subsubsection{Non-aqueous process}

Zinc acetate powder $(0.2 \mathrm{mmol})$ was dissolved in benzyl alcohol $(50 \mathrm{~mL})$ and it was stirred and maintaining $120{ }^{\circ} \mathrm{C}$ until a clear solution was obtained. The mixture was refluxed at three different time intervals of $20 \mathrm{~min}$, 6 and $24 \mathrm{~h}$, at $170{ }^{\circ} \mathrm{C}$, to synthesize the different nanoparticle size of $\mathrm{ZnO}$. The colloidal solution solvent (benzyl alcohol) was replaced with isopropanol using a rotary evaporator and the concentration of $\mathrm{ZnO}$ was adjusted to $0.2 \mathrm{wt} \%$ [25-28]. The different time interval synthesized $\mathrm{ZnO}$ nanoparticle was numbered as, No. 1 of $20 \mathrm{~min}$, No. 2 of $6 \mathrm{~h}$ and No. 3 of $24 \mathrm{~h}$, reflux time respectively.

\subsubsection{Device fabrication}

An inverse type device comprising $\mathrm{FTO} / \mathrm{NiO}_{\mathrm{x}} / \mathrm{MAPbI}_{3} /$ $\mathrm{ZnO} / \mathrm{BCP} / \mathrm{Ag}$ was fabricated in the steps shown in Fig. 1a. The FTO glass substrates (NSG-Pilkington) were cleaned ultrasonically with detergent, distilled water, and ethanol respectively, and treated with $\mathrm{O}_{3}$ for $15 \mathrm{~min}$

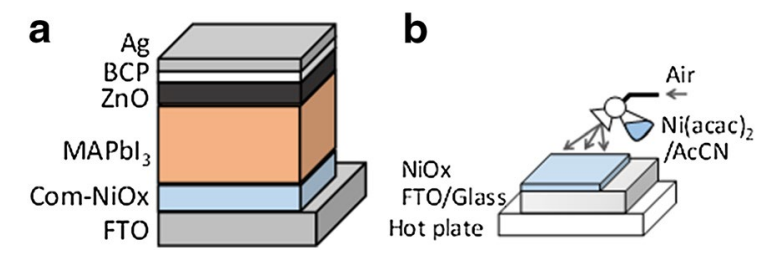

Fig. 1 a Schematic of all inorganic inverted perovskite solar cell structure of $\mathrm{FTO} / \mathrm{NiO}_{x} / \mathrm{MAPbl}_{3} / \mathrm{ZnO} / \mathrm{BCP} / \mathrm{Ag}$. b Schematic of $\mathrm{NiO}_{x}$ layer preparation method using SPD

to eliminate organic impurities and make the surface clean. The substrate arrangements were coated with a dense $\mathrm{NiO}_{x}$ compact layer by spray pyrolysis deposition (SPD) method using a diluted solution of Nickel acetate acetylacetonate in acetonitrile $(0.04 \mathrm{~mol} / \mathrm{L}$ solution, see Fig. 1b). The deposition was carried out at $550{ }^{\circ} \mathrm{C}$ and samples were left on the hot plate until the substrate temperature reached room temperature. A solution of $\mathrm{MAPbI}_{3}$-DMF $(1.8 \mathrm{~mol} / \mathrm{L})$ in DMF was spin-coated at $1000 \mathrm{rpm}$ for $10 \mathrm{~s}$ followed by $5000 \mathrm{rpm}$ for $30 \mathrm{~s}$. During the spin coating, toluene dripping was conducted inside a $\mathrm{N}_{2}$ filled glove box. The film was annealed at $60{ }^{\circ} \mathrm{C}$ for $10 \mathrm{~min}$ and another $100{ }^{\circ} \mathrm{C}$ for $10 \mathrm{~min}$. An inorganic electron acceptor layer was prepared by spin-coated at $1000 \mathrm{rpm}$ for $60 \mathrm{~s}$ from $50 \mu \mathrm{L}, \mathrm{ZnO}$ colloidal solution (at room temperature) on top of the perovskite films. Then, the solution of $\mathrm{BCP}$ in $\mathrm{CH}_{3} \mathrm{OH}(1.0 \mathrm{mg} / \mathrm{mL})$ was filtered through using a $0.45 \mu \mathrm{m}$ cellulose acetate membrane filter, subsequently, was spin-coated at $1000 \mathrm{rpm}$ for $60 \mathrm{~s}$. Finally, Ag back contact layer was coated by thermal evaporation.

\subsubsection{Measurements}

Dynamic light scattering (DLS) measurements were performed using a Malvern Instruments Zetasizer Nano $\mathrm{ZS}$ instrument equipped with a $\mathrm{He}-\mathrm{Ne}$ laser $(4 \mathrm{~mW}$ at $633 \mathrm{~nm}$ ). Measurements were taken at a scattering angle of $173^{\circ}$. XRD patterns were recorded on a Rigaku MiniFlex2 diffractometer working with $\mathrm{Cu} \mathrm{K} \alpha$ radiation.

The photocurrent-voltage $(J-V)$ characteristics of the perovskite solar cells were measured on a B2901A (Agilent Technologies Inc.) source meter under irradiation of AM 1.5, $100 \mathrm{~mW} / \mathrm{cm}^{2}$ (1 sun) supplied by a solar simulator (YSS-80, Yamashita Denso Co., Ltd.). The incident light intensity was calibrated with a reference $\mathrm{Si}$ solar cell (BS-500BK, Bunkoukeiki Co., Ltd.). The active areas of the solar cells were determined with a $0.3 \mathrm{~cm} \times 0.3 \mathrm{~cm}$ black mask. ZnO powders for $\mathrm{x}$-ray diffraction (XRD) characterization were dried on the hot plate at $80^{\circ} \mathrm{C}$. For DLS measurements to measure the size of $\mathrm{ZnO}$ nanoparticles, the concentration was diluted to 25 times using isopropanol. 


\section{Results and discussion}

In order to confirm the crystal structure of the synthesized nanoparticles, the compound powder pattern was confirmed using XRD and are shown in Fig. 2. The characteristic peaks obtained for $\mathrm{ZnO}$ nanoparticles exist at $31.3,33.9,35.8,47.1,56.2,62.4$ and 67.6 correspond to the crystal planes of (100) (002) (101) (102) (110), (013) and (112), respectively. This result clearly indicates that $\mathrm{ZnO}$ nanoparticles were obtained to the $\mathrm{ZnO}$ hexagonal wurtzite structure [29-32]. From the results of XRD, it was confirmed that synthesis of $\mathrm{ZnO}$ nanoparticles was successful using both synthetic routes. However, due to the generated large amount of noise, calculation of the size of $\mathrm{ZnO}$ nanoparticles using XRD could not be performed.

In order to confirm the particle diameter of each synthesized $\mathrm{ZnO}$ nanoparticles, a DLS was used and is shown in Fig. 3. Following the results of DLS, the particle diameters of each different process synthesized $\mathrm{ZnO}$ nanoparticles were calculated. The calculated diameter for aqueous process $\mathrm{H}_{2} \mathrm{O}$, Non-aqueous process No. 1, No. 2 and No. 3, exist for 7, 25, 42 and $75 \mathrm{~nm}$, respectively.

Photovoltaic parameters and conversion efficiency of the all inorganic inverted perovskite solar cells using synthesized four $\mathrm{ZnO}$ nanoparticles are summarized in Table 1 and Fig. 4. In the case of incorporating $\mathrm{ZnO}$ nanoparticles ETL prepared by a non_aqueous process, the performance of the perovskite solar cell was relatively high for the small diameter $\mathrm{ZnO}$ nanoparticle. As a result, fabricated all inorganic perovskite solar cell using the $\mathrm{ZnO}$ nanoparticles ETL having the diameter of $25 \mathrm{~nm}$, the conversion efficiency was obtained $4.3 \%$, current-voltage $(I-V)$ curves and incident photon to current conversion efficiency (IPCE) spectra of this cell are shown in Fig. 4. It was found that with the decrease of $\mathrm{ZnO}$ nanoparticles size the short-circuit current density $(J s c)$ value greatly increases and open circuit photovoltage

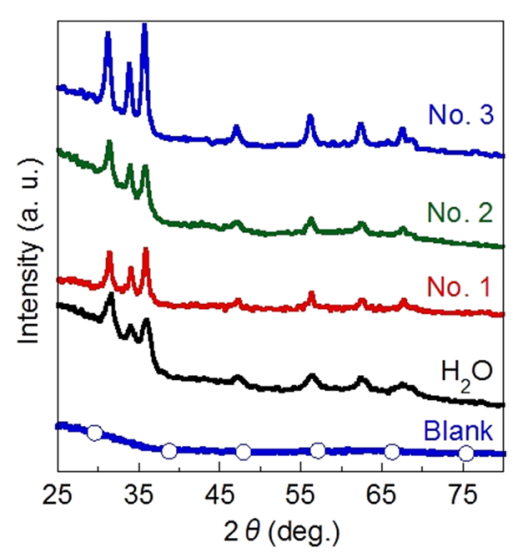

Fig. 2 XRD patterns of $\mathrm{ZnO}$ nanoparticles

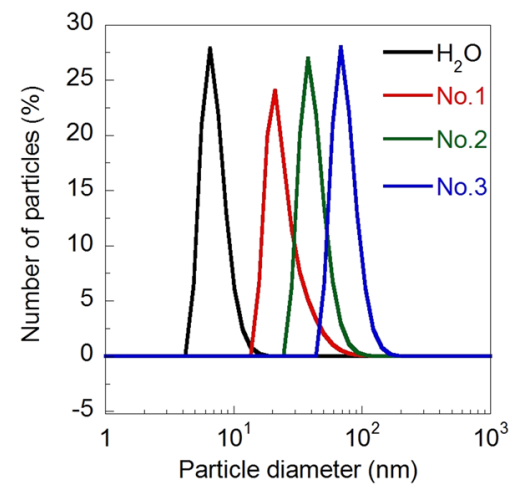

Fig. 3 Number-distributions of hydrodynamic diameter for $\mathrm{ZnO}$ nanoparticles estimated with dynamic light scattering measurements

(Voc) value slightly increases. When the $\mathrm{ZnO}$ nanoparticles with a large diameter $(75 \mathrm{~nm})$ were used as ETL, the $J s c$ value and Voc value show degradation and low conversion efficiency of $0.228 \%$ were observed. From the above results, the $J_{S C}$ value can be increased with the decrease of the diameter $\mathrm{ZnO}$ nanoparticle. The reason for this may be that the use of smaller particles increases the surface area and improves the charge collection capability [33].

Finally, in order to confirm the influence of synthesis route $\mathrm{ZnO}$ nanoparticles, the solar cells were fabricated using aqueous process synthesis method prepared $\mathrm{ZnO}$ nanoparticles as ETL. The perovskite solar cells were left for a day under the $\mathrm{N}_{2}$ glove box and the photograph of the fresh and aged cells are shown in Fig. 5. Despite the $\mathrm{N}_{2}$ atmosphere with very little moisture, the perovskite solar cells using $\mathrm{ZnO}$ nanoparticles ETL prepared by aqueous synthesis process changed its colour from black to yellow in a day. In our previous study, it is clarified that this observed change in the colour is resulting from the decomposition of the perovskite layer by moisture/water [34]. This may result from the synthesis process evolved residue water in fabricated $\mathrm{ZnO}$ nanoparticles. The low $J s c$ value is thought to be due to the effect of residue water emanating from the aqueous synthesis process.

\section{Conclusions}

In conclusion, we fabricated all inorganic inverted perovskite solar cells using synthesized $\mathrm{ZnO}$ nanoparticles and confirmed the optimum size of the $\mathrm{ZnO}$ nanoparticles and the superiority of the synthetic route. We found that $J s c$ and $V o c$ value improves by decreasing the size of $\mathrm{ZnO}$ nanoparticles. Although Voc value is not affected by the influence of residual water in the solution for preparing the $\mathrm{ZnO}$ layer, Jsc value is decreased. As a result, we found two guidelines for manufacturing inorganic perovskite type solar cells with high efficiency; (1) use of 
Table 1 Performance of perovskite solar cell using synthesized ZnO nanoparticles

\begin{tabular}{|c|c|c|c|c|c|c|c|}
\hline Sample & Synthesis method & Scan direction & $J s c\left(\mathrm{~mA} / \mathrm{cm}^{2}\right)$ & $\operatorname{Voc}(\mathrm{V})$ & $F F(-)$ & $\eta(\%)$ & Particle diameter $(\mathrm{nm})$ \\
\hline \multirow[t]{2}{*}{$\mathrm{H}_{2} \mathrm{O}$} & \multirow[t]{2}{*}{ Aqueous process } & Forward & 7.95 & 0.905 & 0.233 & 1.68 & \multirow[t]{2}{*}{7} \\
\hline & & Reverse & 10.1 & 0.867 & 0.136 & 1.19 & \\
\hline \multirow[t]{2}{*}{1} & \multirow[t]{2}{*}{ Non-aqueous process } & Forward & 15.2 & 0.873 & 0.330 & 4.39 & \multirow[t]{2}{*}{25} \\
\hline & & Reverse & 14.7 & 0.850 & 0.336 & 4.25 & \\
\hline \multirow[t]{2}{*}{2} & & Forward & 11.1 & 0.841 & 0.357 & 3.33 & \multirow[t]{2}{*}{42} \\
\hline & & Reverse & 10.2 & 0.845 & 0.376 & 3.25 & \\
\hline \multirow[t]{2}{*}{3} & & Forward & 0.871 & 0.405 & 0.453 & 0.160 & \multirow[t]{2}{*}{75} \\
\hline & & Reverse & 1.10 & 0.417 & 0.645 & 0.296 & \\
\hline
\end{tabular}

Scan direction: forward $J_{S C} \rightarrow V_{O C}$ and reverse: $V_{O C} \rightarrow J_{S C}$. Cell active area is $3 \times 3 \mathrm{~mm}^{2}$ defined by a black mask

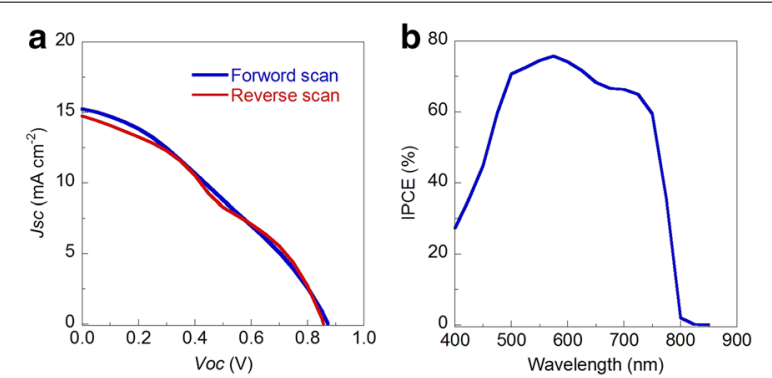

Fig. 4 a $/-V$ curves and $\mathbf{b}$ IPCE spectra measured of fabricated all inorganic perovskite solar cell using the ZnO nanoparticles ETL having diameter of $25 \mathrm{~nm}$

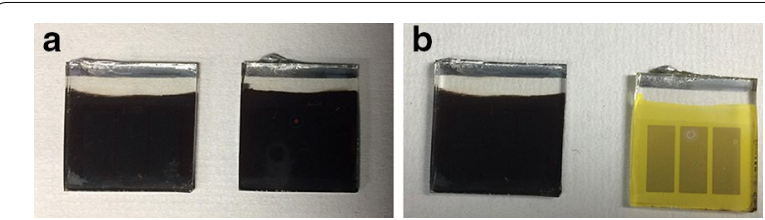

Fig. 5 Photographs of the perovskite solar cells; $\mathbf{a}$ the fresh and $\mathbf{b}$ under the $\mathrm{N}_{2}$ glove box for $24 \mathrm{~h}$. On the left side; the solar cells were fabricated using non-aqueous process synthesis method prepared $\mathrm{ZnO}$ nanoparticles (No. 1). On the right side; the solar cells were fabricated using aqueous process synthesis method prepared $\mathrm{ZnO}$ nanoparticles

oxide nanoparticles with small particle size; (2) reduction of moisture content in oxide forming material. In this experiment, it was impossible to understand the factor given to the fill factor $(F F)$ value. For that reason, we are currently searching for factors that influence the value of $F F$ value by performing internal interface analysis [35-37].

\section{Authors' contributions}

NS carried out the device fabrication, measurement and manuscript writing. HK assisted the device fabrication. SY assisted the measurement. SF, AKB, and SI discussed and helped draft the manuscript. HS, TM, and SI provided the advice on and coordinated the study. All authors read and approved the final manuscript.

\section{Author details}

${ }^{1}$ Department of Materials and Synchrotron Radiation Engineering, Graduate School of Engineering, University of Hyogo, 2167 Shosha, Himeji, Hyogo 671-2280, Japan. ${ }^{2}$ Department of Applied Chemistry, Graduate School of Engineering, University of Hyogo, 2167 Shosha, Himeji, Hyogo 671-2280, Japan. ${ }^{3}$ Research Center for Advanced Science and Technology (RCAST),

The University of Tokyo, 4-6-1 Komaba, Meguro-ku, Tokyo 153-8904, Japan. ${ }^{4}$ Graduate School of Engineering, Toin University of Yokohama, Yokohama, Kanagawa 225-8503, Japan.

\section{Competing interests}

The authors declare that they have no competing interests.

\section{Availability of data and materials}

The authors have no data to share since all data are shown in the submitted manuscript.

\section{Funding and acknowledgements}

This work was supported by New energy and industrial Technology Development Organization (NEDO), Japan.

\section{Publisher's Note}

Springer Nature remains neutral with regard to jurisdictional claims in published maps and institutional affiliations.

Received: 6 June 2017 Accepted: 9 July 2017

Published online: 28 July 2017

\section{References}

1. N.-G. Park, M. Grätzel, T. Miyasaka, K. Zhu, K. Emery, Nat. Energy 1, 16152 (2016)

2. T. Miyasaka, Chem. Lett. 44, $720(2015)$

3. N.-G. Park, Nano Converg. 3, 15 (2016)

S. Ito, APL Mater. 4, 091504 (2016)

5. A. Kojima, K. Teshima, Y. Shirai, T. Miyasaka, J. Am. Chem. Soc. 131, 6050 (2009)

6. J.-H. Im, C.-R. Lee, J.-W. Lee, S.-W. Park, N.-G. Park, Nanoscale 3, 4088 (2011)

7. M.M. Lee, J. Teuscher, T. Miyasaka, T.N. Murakami, H.J. Snaith, Science 338 $643(2012)$

8. W.S. Yang, J.H. Noh, N.J. Jeon, Y.C. Kim, S. Ryu, J. Seo, S.I. Seok, Science $\mathbf{3 4 8}$ 1234 (2015)

9. Best solar cell efficiency chart, http://www.nrel.gov/ncpv/images/efficiency_chart.jpg. Accessed 30 May 2017

10. J. Burschka, N. Pellet, S.J. Moon, R. Humphry-Baker, P. Gao, M.K. Nazeeruddin, M. Grätzel, Nature 499, 316 (2013)

11. Y. Seo, N.-G. Park, Chemsuschem 9, 2528 (2016)

12. S. Ameen, M.A. Rub, S.A. Kosa, K.A. Alamry, M.S. Akhtar, H.S. Shin, H.K. Seo, A.M. Asiri, M.K. Nazeeruddin, Chemsuschem 9, 10 (2016) 
13. J.W. Jo, M.-S. Seo, M. Park, J.-Y. Kim, J.S. Park, I.K. Han, H. Ahn, J.W. Jung, B.-H. Sohn, M.J. Ko, H.J. Son, Adv. Funct. Mater. 26, 4464 (2016)

14. S. Gharibzadeh, B.A. Nejand, A. Moshaii, N. Mohammadian, A.H. Alizadeh, R. Mohammadpour, V. Ahmadi, A. Alizadeh, Chemsuschem 9, 1929 (2016)

15. G.A. Sepalage, S. Meyer, A. Pascoe, A.D. Scully, F. Huang, U. Bach, Y.-B. Cheng, L. Spiccia, Adv. Funct. Mater. 25, 5650 (2015)

16. P. Qin, S. Tanaka, S. Ito, N. Tetreault, K. Manabe, H. Nishino, M.K. Nazeeruddin, M. Grätzel, Nat. Commun. 5, 3834 (2014)

17. M. Jung, Y.C. Kim, N.J. Jeon, W.S. Yang, J. Seo, J.H. Noh, S.I. Seok, Chemsuschem 9, 2592 (2016)

18. V.E. Madhavan, I. Zimmermann, C. Roldán-Carmona, G. Grancini, M. Buffiere, A. Belaidi, M.K. Nazeeruddin, ACS Energy Lett. 1, 1112 (2016)

19. S. Ye, W. Sun, Y. Li, W. Yan, H. Peng, Z. Bian, Z. Liu, C. Huang, Nano Lett. 15 $3723(2015)$

20. S. Chatterjee, A.J. Pal, J. Phys. Chem. C 120, 1428 (2016)

21. J. You, L. Meng, T.-B. Song, T.-F. Guo, Y. Yang, W.-H. Chang, Z. Hong, H. Chen, H. Zhou, Q. Chen, Y. Liu, N. De Marco, Y. Yang, Nat. Nanotechnol. 11, 75 (2015)

22. Z. Zhu, Y. Bai, X. Liu, C.-C. Chueh, S. Yang, A.K.-Y. Jen, Adv. Mater. 28, 6478 (2016)

23. X. Liu, C.-C. Chueh, Z. Zhu, S.B. Jo, Y. Sun, A.K.Y. Jen, J. Mater. Chem. A 4, $15294(2016)$

24. B. Sun, H. Sirringhaus, Nano Lett. 5, 2408 (2005)

25. N. Shibayama, H. Ozawa, M. Abe, Y. Ooyama, H. Arakawa, Chem. Commun. 50, 6398 (2014)
26. N. Shibayama, H. Ozawa, Y. Ooyama, H. Arakawa, Bull. Chem. Soc. Jpn 88, 366 (2015)

27. N. Shibayama, Y. Inoue, M. Abe, S. Kajiyama, H. Ozawa, H. Miura, H. Arakawa, Chem. Commun. 51, 12795 (2015)

28. Y. Adachi, Y. Ooyama, N. Shibayama, J. Ohshita, Chem. Lett. 46, 310 (2017)

29. K. Mahmood, B.S. Swainb, A. Amassiana, Nanoscale 6, 14674 (2014)

30. P. Dhamodharan, C. Manoharan, S. Dhanapandian, M. Bououdina, S. Ramalingam, J. Mater. Sci. Mater. Electron. 26, 4830 (2015)

31. M. Hjiri, L.E. Mir, S.G. Leonardi, Chemosensors 2, 121 (2014)

32. J. Kang, V. Dang, H. Li, S. Moon, P. Li, Y. Kim, C. Kim, H. Choi, Z. Liu, H. Lee, Nano Converg. 3, 34 (2016)

33. R. Zhang, C. Fei, B. Li, H. Fu, J. Tian, G. Cao, ACS Appl, Mater. Interfaces 9 , 9785 (2017)

34. S. Ito, G. Mizuta, S. Kanaya, H. Kanda, T. Nishina, S. Nakashima, H. Fujisawa, M. Shimizu, Y. Haruyama, H. Nishino, Phys. Chem. Chem. Phys. 18, 27102 (2016)

35. N. Shibayama, Y. Zhang, T. Satakea, M. Sugiyama, RSC Adv. 7, 25347 (2017)

36. H. Kanda, A. Uzum, A.K. Baranwal, T.N. Peiris, T. Umeyama, H. Imahori, H. Segawa, T. Miyasaka, S. Ito, J. Phys. Chem. C 120, 28441 (2016)

37. K. Miyanoa, M. Yanagida, N. Tripathi, Y. Shirai, Appl. Phys. Lett. 106, 093903 (2015)

\section{Submit your manuscript to a SpringerOpen ${ }^{\circ}$ journal and benefit from:}

- Convenient online submission

- Rigorous peer review

- Open access: articles freely available online

- High visibility within the field

- Retaining the copyright to your article

Submit your next manuscript at springeropen.com 